DOI: $10.19195 / 2300-7729.35 .2$

\author{
ANNA KOMPERDA \\ Centrum Wiedzy i Informacji Naukowo-Technicznej \\ Politechniki Wrocławskiej
}

\title{
Zmiany w systemie dokumentacji publikacji Politechniki Wrocławskiej na potrzeby Modułu Sprawozdawczego PBN ${ }^{*}$
}

\section{System informacji o nauce}

Jednostki naukowe, które ubiegają się o środki na działalność statutową, od 2015 r. mają obowiązek przekazywania danych dotyczących działalności badawczo-rozwojowej i jej efektów do centralnego Systemu Informacji o Nauce. Ten obowiązek nakłada znowelizowana Ustawa o zasadach finansowania nauki ${ }^{1}$, a terminy aktualizacji danych oraz sposób i formę udostępniania informacji reguluje Rozporządzenie MNiSW w sprawie Systemu Informacji o Nauce $(\mathrm{SIN})^{2}$, które wyznacza obowiązek przekazywania danych w takich obszarach, jak:

1. Podstawowe dane (jednostki naukowej).

2. Informacje o publikacjach w czasopismach naukowych oraz monografiach lub ich rozdziałach autorstwa pracowników jednostki oraz publikacjach osób niebędących pracownikami jednostki, które afiliowały te publikacje do tej jednostki.

3. Informacje o uzyskanych przez jednostkę naukową patentach i prawach ochronnych.

4. Informacje o osiągnięciach artystycznych pracowników jednostki naukowej.

* Artykuł omawia stan prawny i zakres prac przesyłanych do PBN-S do września 2016 r.

${ }^{1}$ Ustawa o zasadach finansowania nauki z dnia 30 kwietnia 2010 r., Dz.U. 2010, nr 96, poz. 615 ze zm., art. 4c., ust. 1.

${ }^{2}$ Rozporządzenie Ministra Nauki i Szkolnictwa Wyższego z dnia 29 czerwca 2015 r. w sprawie Systemu Informacji o Nauce (Dz.U. 2015 r., poz. 944). 
5. Informacje o realizowanych krajowych i międzynarodowych projektach obejmujących badania naukowe lub prace rozwojowe.

6. Informacje o laboratoriach badawczych.

7. Informacje o wdrożonych systemach jakości.

8. Informacje o zorganizowanych konferencjach naukowych.

9. Informacje o nagrodach i wyróżnieniach otrzymanych przez jednostkę naukową i jej pracowników.

10. Informacje o wydawanych przez jednostkę naukową czasopismach naukowych.

11. Informacje o bibliotekach naukowych $\mathrm{w}$ jednostkach naukowych lub w uczelniach.

12. Informacje o realizowanych inwestycjach, nieruchomościach będących w posiadaniu jednostki naukowej lub przez nią użytkowanych oraz infrastrukturze naukowo-badawczej i źródłach jej finansowania.

13. Informacje o wyniku finansowym.

14. Informacje o wdrożeniach wyników badań naukowych lub prac rozwojowych zrealizowanych $\mathrm{w}$ jednostce naukowej i przychodach jednostki naukowej $\mathrm{z}$ tego tytułu.

Celem wymienionych aktów prawnych było stworzenie centralnej bazy danych, która będzie wspierać zarówno MNiSW, jak i inne podmioty działające w obszarze informacji i oceny nauki, m.in. takie jak: Główny Urząd Statystyczny, Centralna Komisja do spraw Stopni i Tytułów Naukowych, NCN, NCBiR. Dane o osiągnięciach naukowych mają być przekazywane do Zintegrowanego Systemu Informacji o Nauce i Szkolnictwie Wyższym „POL-on”. W obszarze gromadzenia informacji o publikacjach ministerstwo powierzyło realizację zadania firmie informatycznej Index Copernicus International (ICI), która uruchomiła centralną bazę - Moduł Sprawozdawczy Polskiej Bibliografii Naukowej (PBN-S) ${ }^{3}$. Niestety, w projektowaniu bazy nie kierowano się opinią środowiska bibliotekarzy ani informatyków tworzących od lat bibliograficzne bazy danych w polskich uczelniach. Nie skorzystano również z gotowych wzorców - systemów sprawnie działających w polskich bibliotekach. Tworzenie oprogramowania od podstaw i jego modyfikacje w trakcie realizacji procesu, ogromny zakres danych wprowadzony rozporządzeniem SIN i wiele niejasności w interpretacji jego zapisów, a także krótki okres realizacji zadania spowodowały ogrom problemów, które musiały być rozwiązane pod presją czasu.

${ }^{3}$ Założenia projektu oraz szczegóły dotyczące jego realizacji z punktu widzenia operatora są przedstawione w: P. Brzeziński, K. Szewczuk, W. Kiliszek, Polska Bibliografia Naukowa. Modut Sprawozdawczy i system POL-index oczami dotychczasowego operatora systemu - nowości, wyzwania, podsumowanie, „Biuletyn EBIB” 2016, nr 165, http://open.ebib.pl/ojs/index.php/ebib/ article/view/432 [dostęp: 14.02.2017]. 


\section{System informacji o nauce w Politechnice Wrocławskiej}

W sprawie podziału zadań oraz trybu przekazywania informacji do poszczególnych modułów systemu POL-on ukazywały się w Politechnice Wrocławskiej regulacje w postaci zarządzeń wewnętrznych. W obecnie obowiązującym zarządzeniu powołano pełnomocnika i koordynatorów odpowiedzialnych za prawidłowość realizacji wymagań ustawowych w zakresie przekazywania danych. Funkcję pełnomocnika Rektora PWr pełni Dyrektor Działu ds. Strategii Uczelni ${ }^{4}$. Kolejne zarządzenie określa szczegółowe zasady oraz mechanizmy przekazywania danych z poszczególnych obszarów informacji gromadzonych i przechowywanych w uczelni ${ }^{5}$. Zgodnie z tym zarządzeniem zadaniem Centrum Wiedzy i Informacji Naukowo-Technicznej (CWINT) jest nadzór, wsparcie, odpowiedzialność i ewidencja danych w takich obszarach jak:

- Polska Bibliografia Naukowa: w oparciu o bazę dorobku naukowego DONA prowadzoną przez Sekcję Analiz Dorobku Naukowego (SADN) we współpracy z Oddziałami CWINT na wydziałach.

- Polska Baza Cytowań POL-index: w oparciu o bazę dorobku naukowego DONA uzupełnianą o cy towania przez Sekcję Informacji Naukowo-Technicznej.

- Ogólnopolskie Repozytorium Pisemnych Prac Dyplomowych: w zakresie nadzoru i wsparcia informatycznego oraz importu masowego z Repozytorium Wiedzy.

- Patenty i dokonania: nadzór merytoryczny i ewidencja informacji na podstawie danych gromadzonych przez Dział Własności Intelektualnej i Informacji Patentowej CWINT.

- Konferencje naukowe: nadzór merytoryczny, przygotowanie i wprowadzanie danych do systemu.

- Czasopisma naukowe wydawane przez jednostkę: nadzór merytoryczny, ewidencja informacji we współpracy z Działem Periodycznych Wydawnictw Naukowych PWr.

- Biblioteki naukowe: ewidencja informacji i „ręczne” zasilanie systemu POL-on.

${ }^{4}$ Zarządzenie Wewnętrzne 18/2015 z dnia 13 kwietnia 2015 r. w sprawie zasad dotyczących realizacji obowiązku przekazywania danych do Zintegrowanego Systemu Informacji o Nauce i Szkolnictwie Wyższym POL-on w Politechnice Wrocławskiej. Zarządzenie Wewnętrzne 83/2015 z dnia 9 listopada 2015 r. zmieniające załącznik nr 2 do ZW 18/2015 (wykaz osób powołanych na Koordynatorów wydziałowych ds. POL-on).

${ }^{5}$ Zarządzenie Wewnętrzne 102/2016 z dnia 2 sierpnia 2016 r. w sprawie zasad przygotowania, ewidencji i przekazywania danych do Zintegrowanego Systemu Informacji o Nauce i Szkolnictwie Wyższym POL-on. 
— Osiągnięcia artystyczne pracowników jednostki: nadzór i wsparcie informatyczne oraz przygotowanie formularza do wprowadzania danych do systemu pośredniczącego (dotyczy prac Wydziału Architektury).

- Projekty naukowe: nadzór merytoryczny we współpracy z Działem Zarządzania Projektami.

Pozostały zakres danych wymaganych w systemie POL-on jest rejestrowany w odpowiednich działach uczelni lub uczelnianym systemie RADoN (Repozytorium Agregowanych Danych o Nauce).

\section{Dokumentacja prac Politechniki Wrocławskiej}

W Politechnice Wrocławskiej (PWr) już od 1972 r. prowadzona jest baza dorobku piśmienniczego DONA. Działalność związana z rejestrowaniem i przetwarzaniem danych o publikacjach i pracach niepublikowanych od początku była realizowana przez bibliotekę, a od 2014 r. jest kontynuowana w Centrum Wiedzy i Informacji Naukowo-Technicznej — nowej jednostce uczelni. System dokumentacji PWr działa w oparciu o zarządzenia wewnętrzne JM Rektora, które od 1969 r. nakładały na pracowników obowiązek zgłaszania prac do biblioteki. W najnowszym zarządzeniu zapis ten został poszerzony o doktorantów, studentów oraz wszystkie osoby realizujące prace w ramach umów cywilnoprawnych na rzecz Politechniki Wrocławskiej ${ }^{6}$. W zakresie oceny merytorycznej i kwalifikacji pracy bibliotekarze mają wsparcie redaktorów naukowych, powoływanych przez władze wydziałów. Weryfikacja danych i kontrola rekordów następuje w Sekcji Analiz Dorobku Naukowego, która koordynuje wszystkie prace związane z rejestrowaniem danych, a także zarządza bazą i całym systemem dokumentacji w uczelni. Rozwój bazy wspierają informatycy, których zadaniem jest tworzenie nowych funkcjonalności, przystosowanie bazy do bieżących potrzeb i wymagań związanych z oceną jednostek i pracowników. Informacje o dorobku są przekazywane na potrzeby władz uczelni, autorów, ankiety jednostki, innych ocen i rankingów. Oprócz podstawowych danych bibliograficznych baza zawiera m.in.: szczegółowe informacje o autorach, punktację artykułów zgodnie z wykazem czasopism punktowanych MNiSW, impact factor, obecność artykułów na liście filadelfijskiej i referatów zarejestrowanych w bazie Web of Science Core Collection, wskaźniki open access, adresy internetowe, identyfikatory DOI, numery grantów/projektów, w ramach których powstała publikacja, oraz cytowania prac. Umożliwia to przekazywanie różnorodnych danych i tworzenie podsumowań statystycznych i naukometrycznych zgodnie z bieżącymi potrze-

${ }^{6}$ Zarządzenie Wewnętrzne 50/2016 w sprawie dokumentowania i rozpowszechniania wyników badań naukowych Politechniki Wrocławskiej, http://www.biblioteka.pwr.wroc.pl/2184882. dhtml [dostęp: 14.02.2017]. 
bami. Baza jest prowadzona w systemie ALEPH, w formacie MARC21 przystosowanym do specyfiki bazy bibliograficznej i zawiera obecnie ponad 206 tys. rekordów. Rocznie jest rejestrowanych ok. 5 tys. publikacji i ok. 1 tys. prac niepublikowanych? ${ }^{7}$.

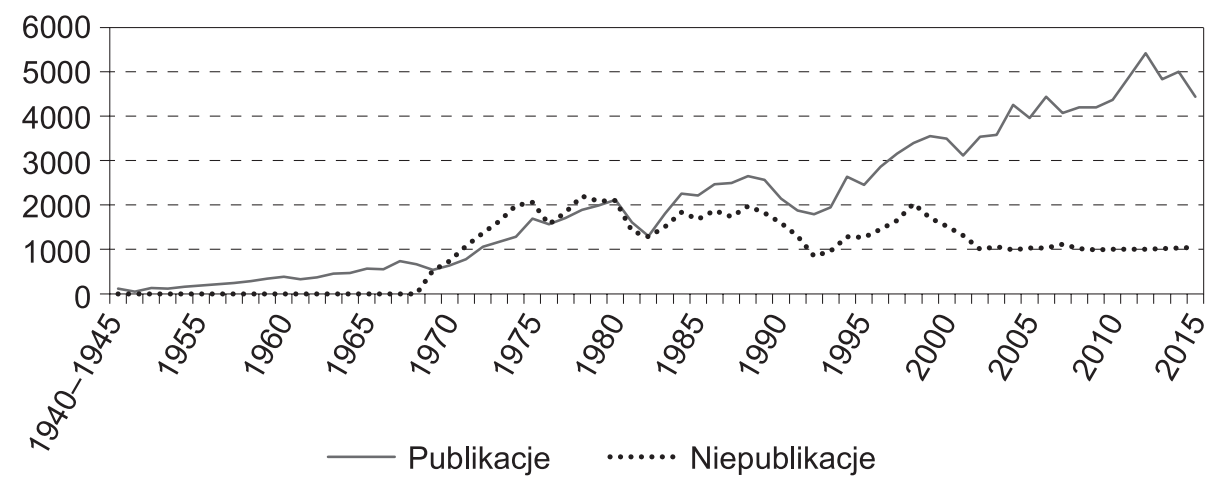

Wykres 1. Liczba publikacji i prac niepublikowanych zarejestrowanych w bazie DONA do $2015 \mathrm{r}$.

Źródło: opracowanie własne na podstawie bazy DONA.

Tabela 1. DONA — liczba prac z najwyższym wskaźnikiem IF w latach 2003-2015

\begin{tabular}{|c|c|c|c|c|c|}
\hline Lp. & Tytuł czasopisma & Rok & IF & Dziedzina wg JCR & Wydział \\
\hline 1. & Chemical Reviews & 2015 & 46.568 & $\begin{array}{l}\text { CHEMISTRY, MULTI- } \\
\text { DISC. }\end{array}$ & Chemiczny \\
\hline 2. & Chem. Soc. Reviews & 2014 & 33.383 & $\begin{array}{l}\text { CHEMISTRY, MULTI- } \\
\text { DISC. }\end{array}$ & Chemiczny \\
\hline 3. & Chemical Reviews & 2010 & 33.036 & $\begin{array}{c}\text { CHEMISTRY, MULTI- } \\
\text { DISC. }\end{array}$ & Chemiczny \\
\hline 4. & Nature & 2004 & 32.182 & MULTIDISCIPLIN. SCI. & PPT \\
\hline 5. & Science & 2003 & 29.781 & MULTIDISCIPLIN. SCI. & Chemiczny \\
\hline 6. & $\begin{array}{l}\text { Nature Rev. Drug } \\
\text { Dis. }\end{array}$ & 2010 & 28.712 & $\begin{array}{l}\text { BIOTECH. a. APPL. } \\
\text { MICR. }\end{array}$ & Chemiczny \\
\hline 7. & Nature Methods & 2013 & 23.656 & BIOCHEM. RES. METH. & PPT \\
\hline 8. & Physics Reports & 2009 & 17.752 & PHYSICS, MULTIDIS. & Elektroniki \\
\hline 9. & Nature Cell Biology & 2007 & 17.623 & CELL BIOLOGY & Chemiczny \\
\hline 10. & Neuron & 2010 & 14.027 & NEUROSCIENCES & Chemiczny \\
\hline
\end{tabular}

${ }^{7}$ A. Komperda, Import publikacji Politechniki Wrocławskiej do Modułu Sprawozdawczego PBN - sprawozdanie z realizacji zadania, „Biuletyn EBIB” 2016, nr 165, http://open.ebib.pl/ojs/ index.php/ebib/article/view/434 [dostęp: 12.02.2017]. 


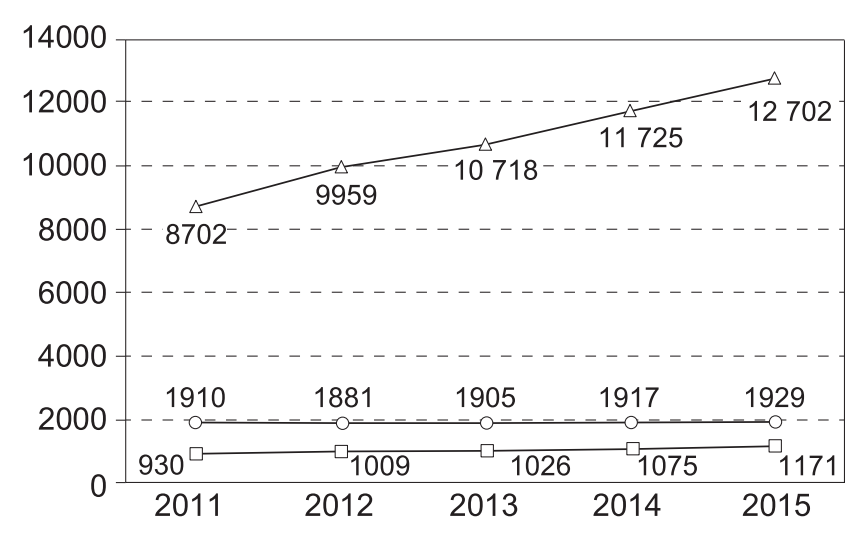

$\square$ pracownicy analizowani $\quad-\circ$ pracownicy cytowani $\quad-$ cytowania

Wykres 2. Cytowania i cytowane publikacje pracowników PWr w latach 2011-2015

Źródło: raport: Analiza cytowań prac naukowych pracowników Politechniki Wrocławskiej za rok 2015.

\section{Import publikacji do Modułu Sprawozdawczego PBN}

\subsection{Organizacja pracy}

W Politechnice Wrocławskiej przyjęto rozwiązanie mające na celu import danych z bazy DONA do Modułu Sprawozdawczego Polskiej Bibliografii Naukowej ${ }^{8}$. Koordynacją całości prac zajmuje się Sekcja Analiz Dorobku Naukowego. Zadaniem SADN jest współpraca z informatykami w zakresie zmian w strukturze bazy DONA, aktualizacja o nowy zakres danych we współpracy z Importerami Publikacji na wydziałach i nadzór mery toryczny nad wykonaniem zadania w całej uczelni. Eksport i import jest dokonywany centralnie przez informatyka CWINT pełniącego funkcję Importera Publikacji dla wszystkich jednostek naukowych PWr, który opracowuje program do eksportu danych, tworzy pliki .xml i wykonuje import do PBN-S. Importerzy Publikacji na wydziałach sprawdzają dane w PBN-S i po konsultacji z dziekanem lub redaktorem naukowym na wydziale zatwierdzają sprawozdanie.

\subsection{Przebieg importu}

Do sierpnia 2016 r. miały miejsce cztery eksporty/importy danych:

1. 29.10-02.11.2015 — publikacje za lata 2013-2015 (do III kw. 2015 r.).

2. 27.01.2016 — publikacje za lata 2013-2015 zdokumentowane w IV kw. 2015 r.

${ }^{8}$ Doświadczenia z przeprowadzenia importu publikacji do PBN-S w 2015 r. są przedstawione w: A. Komperda, op. cit. 
3. 6.06.2016 - ponowny import rekordów uzupełnionych o prace indeksowane w bazach WoSCC, Scopus, objętości w arkuszach wydawniczych, open access i licencje.

4. 8.07.2016 — publikacje za lata 2013-2016 zdokumentowane w okresie 1.01.2016-30.06.2016.

Ogółem dla jednostek naukowych PWr zostało zaimportowanych do PBN-S 12560 prac opublikowanych w latach 2013-2016 (do 30.06.2016). Liczbę prac $\mathrm{z}$ uwzględnieniem publikacji open access, indeksowanych w bazach: Web of Science Core Collection i Scopus oraz liczbę rekordów ze szczegółowymi informacjami o konferencji przedstawiono w tabeli 2.

Tabela 2. Liczba publikacji PWr zaimportowanych do PBN-S za lata 2013-2016 (do 30.06.2016)

\begin{tabular}{|c|c|c|c|c|c|}
\hline \multirow[b]{2}{*}{ Wydział } & \multirow{2}{*}{$\begin{array}{c}\text { Liczba } \\
\text { publikacji }\end{array}$} & \multicolumn{4}{|c|}{ W tym publikacje: } \\
\hline & & $\mathrm{OA}$ & $\begin{array}{l}\text { Web of } \\
\text { Science }\end{array}$ & Scopus & $\begin{array}{l}\mathrm{z} \text { informacją } \\
\text { o konferencji }\end{array}$ \\
\hline Architektury & 949 & 180 & 41 & 54 & 288 \\
\hline $\begin{array}{l}\text { Budownictwa Lądowego } \\
\text { i Wodnego }\end{array}$ & 1176 & 232 & 50 & 89 & 432 \\
\hline Chemiczny & 1371 & 314 & 25 & 32 & 246 \\
\hline Elektroniki & 1371 & 231 & 346 & 447 & 769 \\
\hline Elektryczny & 834 & 305 & 80 & 105 & 305 \\
\hline $\begin{array}{l}\text { Geoinżynierii, } \\
\text { Górnictwa i Geologii }\end{array}$ & 413 & 137 & 32 & 27 & 164 \\
\hline Inżynierii Środowiska & 697 & 157 & 12 & 19 & 158 \\
\hline $\begin{array}{l}\text { Informatyki } \\
\text { i Zarządzania }\end{array}$ & 1206 & 284 & 180 & 295 & 459 \\
\hline $\begin{array}{l}\text { Mechaniczno- } \\
\text {-Energetyczny }\end{array}$ & 586 & 122 & 30 & 36 & 285 \\
\hline Mechaniczny & 1661 & 348 & 66 & 125 & 795 \\
\hline $\begin{array}{l}\text { Podstawowych } \\
\text { Problemów Techniki }\end{array}$ & 952 & 239 & 84 & 120 & 301 \\
\hline $\begin{array}{l}\text { Elektroniki } \\
\text { Mikrosystemów i Fotoniki }\end{array}$ & 414 & 97 & 98 & 134 & 315 \\
\hline Matematyki* & 70 & 19 & 5 & 9 & 14 \\
\hline $\begin{array}{l}\text { Techniczno-Informatyczny } \\
\text { (Jelenia Góra)* }\end{array}$ & 18 & 6 & 0 & 2 & 0 \\
\hline
\end{tabular}




\begin{tabular}{|l|r|r|r|r|c|}
\hline $\begin{array}{l}\text { Techniczno-Inżynieryjny } \\
\text { (Wałbrzych)* }\end{array}$ & 11 & 1 & 0 & 0 & 0 \\
\hline $\begin{array}{l}\text { Techniczno-Przyrodni- } \\
\text { czy (Legnica)* }\end{array}$ & 12 & 1 & 0 & 0 & 0 \\
\hline OGÓŁEM PWR & 12560 & 2628 & 978 & 1425 & 4407 \\
\hline
\end{tabular}

*wydziały utworzone w 2015 r.

\subsection{Zakres danych o publikacji}

Zakres informacji o publikacjach objętych obowiązkiem sprawozdawczym budzi wiele kontrowersji. Oprócz podstawowych danych bibliograficznych jest tu wiele dodatkowych informacji nierejestrowanych do tej pory w bazach publikacji, m.in. o afiliacji pracy do jednostki w roku opublikowania, o konferencjach, indeksowaniu w bazach danych, np. Scopus, a przede wszystkim o otwartym dostępie i licencjach OA. Poniżej zostały przedstawione rozwiązania przyjęte w bazie DONA, które umożliwiły jej uzupełnienie o wymagane dane.

\subsubsection{Dane o autorach i redaktorach}

Dla publikacji w czasopismach naukowych dane o autorach obejmują:

— imiona i nazwiska autorów publikacji będących w roku jej wydania pracownikami jednostki naukowej i afiliujących publikację do jednostki,

— imiona i nazwiska pozostałych autorów publikacji niebędących w roku jej wydania pracownikami jednostki naukowej, ale afiliujących publikację do jednostki,

- liczbę pozostałych autorów, którzy nie byli zatrudnieni i nie afiliowali publikacji do jednostki naukowej.

Dodatkowo dla monografii naukowych i ich rozdziałów:

— imiona i nazwiska redaktorów naukowych będących w roku ich wydania pracownikami jednostki naukowej i afiliujących publikację do jednostki,

— imiona i nazwiska pozostałych redaktorów publikacji niebędących w roku jej wydania pracownikami jednostki naukowej, ale afiliujących publikację do jednostki,

- liczbę pozostałych redaktorów niebędących w roku jej wydania pracownikami jednostki naukowej i nieafiliujących publikacji do jednostki ${ }^{9}$.

W bazie DONA informacje o autorach/redaktorach są gromadzone w kartotece KHW na podstawie danych osobowych pozyskiwanych z Działu Zarządzania Zasobami Ludzkimi PWr. Od początku funkcjonowania bazy jest wykorzystywany numer identyfikujący autora i jego dorobek w zbiorze. Numery są również nadawane

${ }^{9}$ Zgodnie z rozporządzeniem SIN poz. 944,pkt 2.1) a-c; pkt 2.2) a-c; 2.3) b-d oraz interpretacją MNiSW zamieszczoną na stronie PBN-OPI, https://pbn-ms.opi.org.pl/pbn-report-web/. 
doktorantom i studentom. Dla autorów niezatrudnionych w PWr zakłada się KHW, podając tylko imię i nazwisko z numerem ewidencyjnym wspólnym dla wszystkich - w postaci sześciu zer (000000). Pozwala to odróżnić autorów z i spoza PWr oraz podać ich liczbę w PBN-S. Na potrzeby importu do PBN-S w bazie opisów bibliograficznych prac, w polach „Hasło osobowe” 100,700 zostały dodane nowe podpola informujące o zatrudnieniu i afiliacji pracy. Taki zapis pozwala na właściwy import danych w schemacie wymaganym w PBN-S wraz liczbą autorów niezatrudnionych i nieafiliujących pracy do jednostki. Przykłady:

\section{Zapis w bazie DONA:}

100,700 a Nowak, Jan (zatrudniony, afiliuje pracę)

b 203344 (numer ewidencyjny autora w bazie DONA)

g W01 (kod Wydz. Architektury, jeżeli praca afiliowana do jednostki)

h W01/K01 (kod Katedry na Wydz. Architektury — miejsce pracy autora)

Zapis pliku w schemacie .xml PBN-S:

$<$ author $>$

$<$ given-names $>$ Jan $<$ given-names $>$

$<$ family-name $>$ Nowak $<$ /family-name $>$

$<$ system-identifier $>203344<$ /system-identifier $>$

$<$ affiliated-to-unit $>$ true $</$ affiliated-to-unit $>$

$<$ employed-in-unit $>$ true $<$ /employed-in-unit $>$

$</$ author $>$

2. Zapis w bazie DONA:

100,700 a Nowak, Jan (zatrudniony, brak afiliacji pracy)

b 203344 (numer ewidencyjny autora w bazie DONA)

g - (brak kodu jednostki — praca nieafiliowana do jednostki)

h W01/K01 (kod Katedry na Wydz. Architektury — miejsce pracy autora)

Zapis pliku w schemacie .xml PBN-S:

$<$ author $>$

$<$ given-names $>$ Jan $<$ given-names $>$

$<$ family-name $>$ Nowak $<$ /family-name $>$

$<$ system-identifier $>203344<$ /system-identifier $>$

$<$ affiliated-to-unit $>$ false $<$ /affiliated-to-unit $>$

$<$ employed-in-unit $>$ true $</$ employed-in-unit $>$

$</$ author $>$

3. Zapis w bazie DONA:

100,700 a Nowak, Jan (emeryt — niezatrudniony, afiliuje pracę)

b 203344 (numer ewidencyjny autora w bazie DONA) 
g W01 (kod Wydz. Architektury, jeżeli praca afiliowana do jednostki)

$\mathrm{h}$ - (brak kodu jednostki)

Zapis pliku w schemacie .xml PBN:

$<$ author $>$

$<$ given-names $>$ Jan $<$ /given-names $>$

$<$ family-name $>$ Nowak $<$ /family-name $>$

$<$ system-identifier $>203344</$ system-identifier $>$

$<$ affiliated-to-unit $>$ true $</$ affiliated-to-unit $>$

$<$ employed-in-unit $>$ false $</$ employed-in-unit $>$

$<$ /author $>$

4. Zapis w bazie DONA:

100,700 a Nowak, Jan (niezatrudniony, brak afiliacji pracy)

b 000000 (numer ewidencyjny autora w bazie DONA)

$\mathrm{g}$ - (brak kodu jednostki, praca nieafiliowana do jednostki)

$\mathrm{h}-$ (brak kodu jednostki)

Zapis pliku w schemacie .xml PBN-S:

$<$ other-contributors $>1</$ other-contributors $>$

Decyzją MNiSW przekazaną w dniu 30 lipca 2016 r. należy podawać dane redaktorów całej monografii przy sprawozdawaniu rozdziałów ${ }^{10}$. Uzupełnienie ich nazwisk i afiliacji oznacza konieczność wyszukania informacji na podstawie publikacji, co w przypadku prac drukowanych będzie często trudne, a przeszukiwanie innych źródeł w Internecie — czasochłonne. Interpretacja MNiSW podana po terminie obowiązkowych dwóch importów i w trakcie trzeciego jest kolejnym utrudnieniem $w$ procesie sprawozdawania i zatwierdzania prac. Następnym problemem w przypadku autorów i redaktorów będzie właściwe ich powiązanie z danymi o pracownikach nauki, które są przekazywane przez jednostki do systemu POL-on. Rozwiązanie tego problemu leży po stronie obecnego operatora bazy PBN, czyli Ośrodka Przetwarzania Informacji, którego zadaniem będzie integracja danych o autorach prac zaimportowanych do PBN-S z odpowiednim modułem w systemie POL-on.

\subsubsection{Dane o konferencjach}

Zgodnie z SIN, poz. 944 dane o konferencjach obejmują:

- nazwę konferencji pełną i skróconą,

— datę rozpoczęcia i zakończenia (w postaci dzień-miesiąc-rok),

${ }^{10}$ PBN - Polska Bibliografia Naukowa, https://pbn.nauka.gov.pl/sedno-webapp/ [dostęp: $3.08 .2016]$. 
— kod języka (publikacji),

— kod państwa (miejsca odbycia konferencji) ${ }^{11}$.

Konieczność podawania tak szczegółowych danych budzi wiele wątpliwości. Nie były one do tej pory uwzględniane w opisie publikacji w bazie DONA i na pewno w wielu bazach bibliograficznych innych jednostek naukowych. Zasady opisu bibliograficznego nie wymagają tak szczegółowych danych w przypadku rejestrowania materiałów pokonferencyjnych. Aby właściwie je przekazać do PBN-S, w bazie DONA zostało zmodyfikowane pole 711 „Hasło dodatkowe — opis konferencji” oraz podpola umożliwiające zapis danych. Spowodowało to również konieczność wyszukania publikacji od 2013 r. i uzupełnienia informacji w ponad 4 tys. rekordów (zob. tab. 2. Publikacje z informacją o konferencji).

\section{HASLO DODATKOWE - OPIS KONFERENCJI (P)}

Identyfikatory podpó 1

a Narwa konferencji (NP)
b Skrócona nazwa konferencji (NP)
d Data konferencji (NP)
c Miejsce konferencji (P)
m Kod kraju konferencji (P)

Rys. 1. DONA-ALPEH — pole „opis konferencji” na formularzu wprowadzania danych

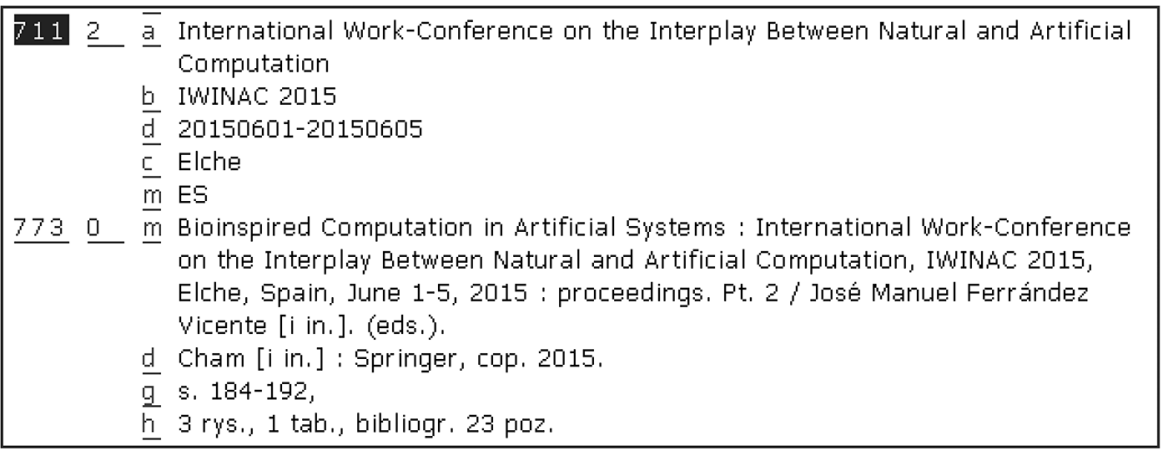

Rys. 2. DONA-ALEPH — zapis informacji o konferencji w rekordzie bibliograficznym pracy

Zgodnie z koniecznością zamieszczania w materiałach pokonferencyjnych informacji o indeksowaniu w bazach czasopism i abstraktów: Web of Science ${ }^{\mathrm{TM}}$ Core Collection, Scopus lub w innych bazach danych uznanych w środowisku naukowym danej dyscypliny naukowej za spełniające kryterium powszechnej do-

${ }^{11}$ Zgodnie z rozporządzeniem SIN, pkt 2.1) k; 2.2)1; 2.3)k. 
stępności ${ }^{12}$ wszystkie publikacje zarejestrowane w bazie DONA opublikowane od roku 2013 zostały sprawdzone we wskazanych bazach (tab. 2. Publikacje z Web of Science i Scopus). Rejestrowanie tych informacji odbywa się na bieżąco lub jest systematycznie sprawdzane dla prac już zdokumentowanych i uzupełniane w sprawozdaniach PBN-S.

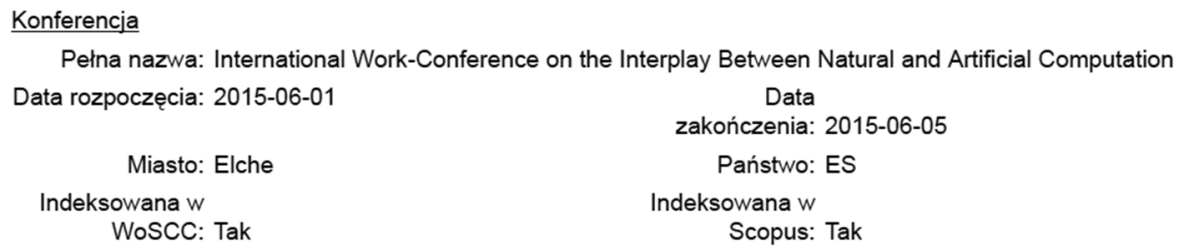

Rys. 3. Sprawozdanie PBN-S jednostki PWr. Przykład rekordu — rozdział z monografii, dane o konferencji i obecność w bazach WoSCC i Scopus

Problemem są , ,inne uznane bazy”, ponieważ nigdzie nie ma odwołania do wykazu baz ani do kryteriów tej „uznaniowości”. Jeśli taka lista baz ukaże się w 2017 r., to prawdopodobnie wymusi dodatkowe sprawdzanie materiałów pokonferencyjnych od 2013 r.!

\subsubsection{Informacje o czasopiśmie}

Dane o czasopiśmie obejmują pełną nazwę czasopisma naukowego, numer ISSN oraz (jeżeli został nadany) identyfikator DOI czasopisma naukowego (Digital Object Identifier). Problem podawania pełnej nazwy czasopisma dotyczy różnicy między wersją rejestrowaną w bazie DONA - ustalaną na podstawie danych z autopsji i właściwych źródeł, jak np. bazy ISSN, Ulrichs, Nukat — a wersjami zamieszczanymi na liście czasopism punktowanych MNiSW, które w wielu wypadkach są nieaktualne lub błędne, np. bez polskich liter. Różnice w tytułach zaimportowanych z lokalnych baz jednostek w stosunku do list MNiSW mogą skutkować odrzuceniem tych danych w programie przyszłej ankiety jednostki i niezaliczeniem punktów publikacjom. Zapowiedź ministerstwa o zastosowaniu jednej, ujednoliconej listy czasopism za lata 2013-2016 w ankiecie jednostki w 2017 r. dodatkowo budzi niepokój o wybór wersji tytułu. Zastosowanie kryterium numeru ISSN też może nie stanowić rozwiązania problemu. Dotychczasowe doświadczenia PWr w eksporcie danych do programu ankiety w roku 2013 wskazują, że tylko częściowo był to proces automatyczny i w wielu przypadkach wymagał ręcznego poprawiania, ponieważ tylko tytuły w wersji identycznej z listą

12 Rozporządzenie Ministra Nauki i Szkolnictwa Wyższego w sprawie Systemu Informacji o Nauce, s. 4, 2.1)k), 2.2)l), 2.3)k). 
tytułów czasopism MNiSW (nawet jeżeli były błędne!) pozwalały na prawidłowe wczytanie do programu i naliczenie punktów.

Wątpliwości dotyczą również podawania numeru DOI dla czasopisma naukowego $^{13}$, ale także poszczególnych publikacji. DOI dla całego tytułu nie jest uwzględniana w sprawozdaniach jednostek PWr, ponieważ jest podawany nr DOI poszczególnych prac, co jednoznacznie je identyfikuje w zasobach sieci.

\subsubsection{Informacje o monografiach i ich rozdziałach}

Rozporządzenie SIN nakazuje sprawozdawanie monografii naukowych, w tym monografii naukowych wieloautorskich, w których nie określono autorów poszczególnych rozdziałów, oraz publikacji w rozdziałach z monografii naukowych wieloautorskich, w których określono autorów poszczególnych rozdziałów, nie podając przy tym ich definicji ${ }^{14}$. Zapis dotyczący monografii jest zawarty w opublikowanym 27 października 2015 r. rozporządzeniu MNiSW w sprawie kryteriów i trybu przyznawania kategorii naukowej jednostkom naukowym, które miało obowiązywać od 1 stycznia 2017 r. ${ }^{15}$ Niestety w 2016 r. rozpoczęły się prace nad projektem nowego rozporządzenia, które może zmienić zapisy w wielu kwestiach. Dodatkowo początkową interpretację dotyczącą przesyłania tylko prac spełniających kryteria monografii wraz z obowiązkową objętością zastąpiła sugestia o przesyłaniu wszystkich publikacji, z których właściwe zostaną wczytane do przyszłej ankiety jednostki ${ }^{16}$.

W bazie DONA te prace są rejestrowane jako monografie, habilitacje, inne książki naukowe, redaktorstwa monografii i prac zbiorowych, rozdziały w książkach i referaty. Ważną rolę w ich ocenie merytorycznej i zatwierdzaniu do PBN-S mają redaktorzy naukowi lub władze jednostek.

Rozporządzenie SIN w punkcie przedstawiającym zakres danych o monografiach i ich rozdziałach uwzględnia tylko nr ISBN, nie dając możliwości podania numeru ISSN. Wydawanie monografii w seriach, z nadanym tylko numerem ISSN jest od dawna stosowaną praktyką wydawniczą. Niestety, pomimo zgłaszania tego problemu przez uczelnianego przedstawiciela POL-on na szkoleniach oraz e-mailem, ten błąd nie został naprawiony. Brak możliwości masowego importu takich prac z bazy DONA zastąpiono ,ręcznym” wpisem w programie Modułu Sprawozdawczego, licząc na uwzględnienie tych prac w ocenie jednostki.

13 Zgodnie z rozporządzeniem SIN, pkt 2.1)e.

${ }^{14}$ Zgodnie z rozporządzeniem SIN, pkt 2.2) i 2.3).

15 Rozporządzenie Ministra Nauki i Szkolnictwa Wyższego z dnia 27 października 2015 r. w sprawie kryteriów i trybu przyznawania kategorii naukowej jednostkom naukowym, Dz.U. 2015, poz. 2015.

${ }^{16}$ Informacje przekazywane na szkoleniach organizowanych przez firmę ICI i OPI. 


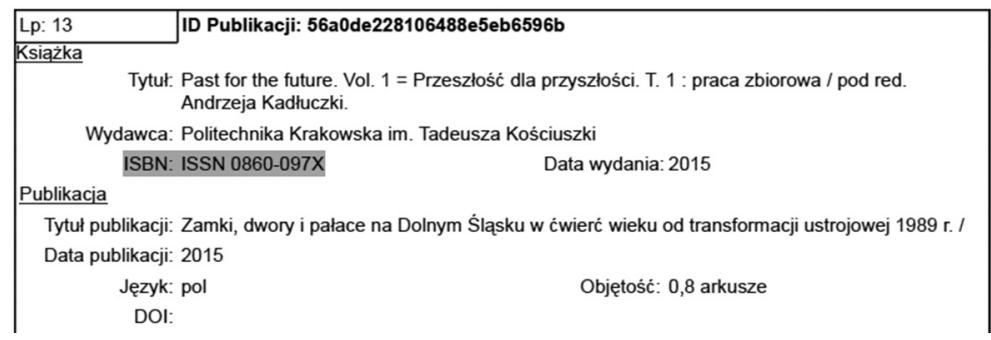

Rys. 4. Zapis monografii z numerem ISSN w PBN-S Źródło: PBN-S. Sprawozdanie jednostki PWr.

\subsubsection{Informacje o otwartym dostępie (open access)}

Informacja o otwartym dostępie do publikacji jest obowiązkowo wymagana we wszystkich typach sprawozdawanych prac $^{17}$. Ich zakres w tym obszarze zawiera dane o sposobie udostępniania (witryna wydawcy, otwarte repozytorium, inne); wersji tekstu, który jest dostępny w sposób otwarty (oryginalna wersja autorska, ostateczna wersja autorska, ostateczna wersja opublikowana); otwartej licencji (CC-BY, CC-BY-SA, CC-BY-NC, CC-BY-ND, CC-BY-NC-SA, CC-BY-NC-ND); innej otwartej licencji; informacji o momencie udostępnienia monografii w sposób otwarty (przed opublikowaniem, w momencie opublikowania, po opublikowaniu — wraz z podaniem liczby miesięcy, jakie upłynęły od momentu opublikowania do momentu udostępnienia publikacji w sposób otwarty). Jest to ogromny zakres danych, które trzeba sprawdzić i wprowadzić do rekordu każdej pracy.

W celu wykazania informacji o otwartym dostępie do struktury bazy DONA dodano pola lokalne: WOA — „Wskaźnik open access” oraz LOA — „Informacje o rodzaju licencji” i innych wymaganych danych wraz z instrukcją ich wypełniania. Aby sprawdzić poprawność wypełniania pól w systemie ALEPH, opracowano również zestaw raportów kontrolnych, dzięki którym można monitorować prawidłowy zestaw danych. Systematyczne generowanie raportów kontrolnych pozwala na szybkie znalezienie błędów i ich poprawę w bazie. Liczba publikacji open access zaimportowanych do PBN-S jest podana w tabeli 2. Dane są zbierane na podstawie informacji podanych na stronach publikacji, wydawców, repozytoriów, baz Sherpa/Romeo, DOAJ. Niestety, wielu wydawców nie podaje takich informacji, a wiedza autorów jest w tym względzie także niedostateczna.

Zgodnie z polityką otwartego dostępu ${ }^{18} \mathrm{MNiSW}$ wymaga w ramach sprawozdań szerokiego zakresu informacji na ten temat. Wiedza o open access jest

${ }^{17}$ Zgodnie z rozporządzeniem SIN, pkt 2.1)i; 2.2)j; 2.3)i.

18 Zalecenie KE z dnia 17 lipca 2012 r. ws. dostępu do informacji naukowej oraz jej ochrony (2012/417/UE): OA jest wymagany w Programie H2020. 
jednak wciąż niewystarczająca i trudna do uzyskania. Nie wszystkie wydawnictwa czy serwisy (DOAJ, Sherpa/Romeo) jasno informują o udostępnianiu w modelu OA, rodzaju licencji, momencie ich udostępnienia! Szczegółowe dane o licencjach powinny być podane przez polskie redakcje w trakcie zgłaszania czasopisma do oceny lub przez repozytoria, które mają już taką wiedzę o deponowanych zasobach. Przekazywanie informacji do PBN-S z często różniącymi się danymi dla tej samej pracy lub jej brak spowoduje, że sprawozdania jednostek nie będą rzetelnym źródłem danych o OA. Przykładem może tu być analiza wykonana na podstawie tytułu polskiego czasopisma „Materials Science-Poland" wydawanego na licencji CC-BY-NC-ND ${ }^{19}$. Przegląd sprawozdań kilku jednostek innych uczelni wskazuje, że przekazane publikacje nie zawierają informacji o OA.

\section{Wnioski}

Celem niniejszej pracy było pokazanie działań podejmowanych w Centrum Wiedzy Naukowo-Technicznej Politechniki Wrocławskiej w zakresie rozwijania bazy dorobku naukowego na potrzeby przyszłej oceny jednostek. Nowe zadania wymusiły uzupełnianie danych o dodatkowe informacje, a także rozbudowę struktury bazy oraz inny sposób zapisu wielu elementów. Obecnie baza zawiera zestaw danych odpowiadających wymogom parametryzacji i jest przystosowana pod względem zarówno informacyjnym, jak i informatycznym do obsługi polskiego Systemu Informacji o Nauce. System jest budowany z wykorzystaniem oprogramowania ALEPH i zapewnia eksport plików .xml w formacie akceptowanym przez PBN-S. W bazie są gromadzone dane o autorach, pracach, źródłach ich finansowania, indeksowaniu w innych bazach danych, udostępnianiu w modelu open access, adresach URL, wskaźnikach naukometrycznych i wiele innych. Przeprowadzone do tej pory importy potwierdziły jej przydatność do tego celu. Nowe zakresy opisu prac wymagają jednak systematycznego uzupełnienia danych, sprawdzania w wielu źródłach i bieżącej kontroli. Jest to zadanie wykonywane przez zespół bibliotekarzy, którzy mają także powierzone obowiązki Importera Publikacji, czyli osoby odpowiedzialnej w jednostkach za zatwierdzanie sprawozdań. Ten nowy zakres odpowiedzialności znacząco poszerzył kompetencje bibliotekarzy i pozwolił na uzyskanie nowych doświadczeń, jak też wzmocnił współpracę z władzami jednostek.

Stworzenie zintegrowanego sytemu informacji o dorobku publikacyjnym jednostek naukowych i jej pracowników na poziomie kraju to konieczność. Systematyczne przekazywanie tych danych do centralnej bazy i wszechstronne jej wykorzystanie powinno być priorytetem. Ważny jest jednakże sposób realizacji zadania:

19 Wrockaw University of Science and Technology, „Materials Science-Poland”, http://www. materialsscience.pwr.wroc.pl/ [dostęp: 12.02.2017]. 


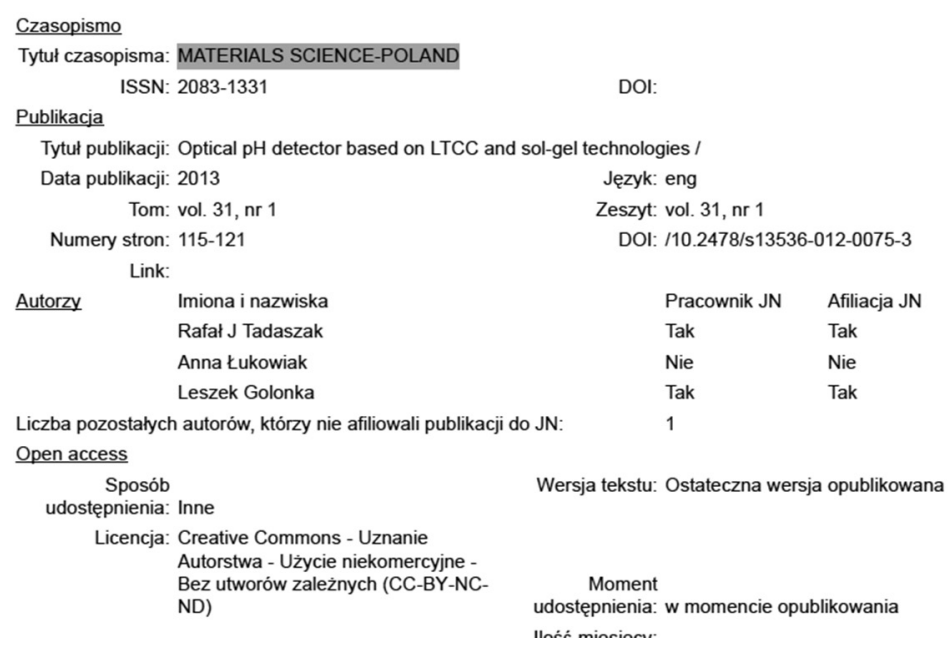

Rys. 5. PBN-S. Sprawozdanie jednostki PWr z publikacją w czasopiśmie OA „Materials Science-Poland”

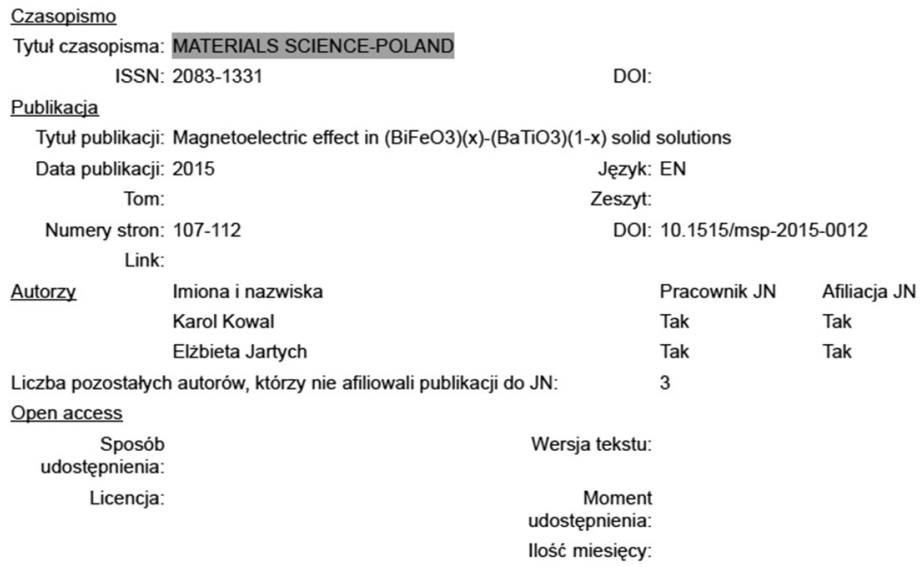

Rys. 6. PBN-S. Sprawozdanie jednostki innej uczelni bez informacji OA w publikacji z czasopisma „Materials Science-Poland”

jasne kryteria i zakres danych podanych z odpowiednim wyprzedzeniem. Tego jednak zabrakło. Problemem było uzupełnienie danych o pracach od 2013 r., niejednoznaczne zapisy w rozporządzeniu SIN i ich interpretacja, tworzenie infrastruktury informatycznej PBN-S w trakcie realizacji zadania, co nie sprzyjało poprawnemu testowaniu własnych oprogramowań eksportujących dane. W dodatku w kwietniu 2016 r. został powołany nowy operator systemu — OPI, który wprowadził liczne zmiany w interfejsie bazy i sposobie sprawozdawania. Ponadto nieznane są ostateczne wersje rozporządzeń: w sprawie kryteriów i trybu przyznawania kategorii naukowej jednostkom naukowym oraz Systemu Informacji o Nauce, które są w trakcie nowelizacji. Prawdopodobnie spowoduje to kolejną zmianę w wymaganym zakresie 
danych o publikacjach i programie PBN-S. Jest to powodem do niepokoju wszystkich biorących udział w realizowaniu tego zadania, ponieważ spójność danych i ich poprawność będzie miała fundamentalne znaczenie dla oceny jednostek naukowych i polskiej nauki. Można tylko mieć nadzieję, że zakres, format zapisu i kompletność danych zgromadzonych do tej pory w Module Sprawozdawczym Polskiej Bibliografii Naukowej będą podstawą do przeprowadzenia w roku 2017 oceny parametrycznej jednostek bez konieczności ponownego ich wysyłania.

\section{Bibliografia}

Brzeziński P., Szewczuk K., Kiliszek W., Polska Bibliografia Naukowa. Modut Sprawozdawczy i system POL-index oczami dotychczasowego operatora systemu — nowości, wyzwania, podsumowanie, „Biuletyn EBIB” 2016, nr 165, http://open.ebib.pl/ojs/index.php/ebib/article/view/432 [dostęp: 14.02.2017].

Komperda A., Import publikacji Politechniki Wrocławskiej do Modułu Sprawozdawczego PBNsprawozdanie z realizacji zadania, „Biuletyn EBIB” 2016, nr 165 http://open.ebib.pl/ojs/index. php/ebib/article/view/434 [dostęp: 12.02.2017].

Komperda A., Urbańczyk B., DONA — baza dorobku naukowego Politechniki Wrocławskiej źródtem wiedzyo potencjale naukowym uczelni, [w:] Infobazy 2014: inspiracja - integracja - implementacja: VII krajowa konferencja naukowa, Gdańsk-Sopot 8-10 września 2014 r., Gdańsk [2014] s. 1-8.

PBN. Polska Bibliografia Naukowa, https://pbn.nauka.gov.pl/sedno-webapp/, https://pbn-ms.opi.org. pl/pbn-report-web/ [dostęp: 14.02.2017].

PBN. Polska Bibliografia Naukowa. Szczegótowy opis formatu plików importu, [w:] Pomoc PBN, http://pbn-pomoc.opi.org.pl/index.php?option=com_content\&view $=$ article\&id=217\&Itemi$\mathrm{d}=231 \&$ lang=pl [dostęp: 10.05.2016].

Rozkosz E., Drabek A., Modut Sprawozdawczy Polskiej Bibliografii Naukowej, „Biuletyn EBIB” 2016, nr 165, http://open.ebib.pl/ojs/index.php/ebib/article/view/438 [dostęp: 14.02.2017].

Rozporządzenie Ministra Nauki i Szkolnictwa Wyższego z dnia 29 czerwca 2015 r. w sprawie Systemu Informacji o Nauce (Dz.U. 2015, poz. 944).

Rozporządzenie Ministra Nauki i Szkolnictwa Wyższego z dnia 26 lutego 2016 r. zmieniające rozporządzenie w sprawie Systemu Informacji o Nauce, Dz.U. 2016, poz. 309.

Rozporządzenie Ministra Nauki i Szkolnictwa Wyższego z dnia 27 października 2015 r. w sprawie kryteriów i trybu przyznawania kategorii naukowej jednostkom naukowym, Dz.U. 2015, poz. 2015.

Ustawa o zasadach finansowania nauki z dnia 30 kwietnia 2010 r., Dz.U. 2010, nr 96, poz. 615 ze zm.

Wrockaw University of Science and Technology, „Materials Science-Poland”, http://www.materialsscience.pwr.wroc.pl/ [dostęp: 12.02.2017].

Zarządzenie Wewnętrzne 18/2015 z dnia 13 kwietnia 2015 r. w sprawie zasad dotyczących realizacji obowiązku przekazywania danych do Zintegrowanego Systemu Informacji o Nauce i Szkolnictwie Wyższym POL-on w Politechnice Wrocławskiej.

Zarządzenie Wewnętrzne 83/2015 z dnia 9 listopada 2015 r. zmieniające załącznik nr 2 do ZW 18/2015 (wykaz osób powołanych na Koordynatorów wydziałowych ds. POL-on).

Zarządzenie Wewnętrzne 50/2016 w sprawie dokumentowania i rozpowszechniania wyników badań naukowych Politechniki Wrocławskiej, http://www.biblioteka.pwr.wroc.pl/2184882.dhtml [dostęp: 14.02.2017]. 
Zarządzenie Wewnętrzne 102/2016 z dnia 2 sierpnia 2016 r. w sprawie zasad przygotowania, ewidencji i przekazywania danych do Zintegrowanego Systemu Informacji o Nauce i Szkolnictwie Wyższym POL-on.

\title{
Changes in documentation system of publications of the Wrocław University of Science and Technology in the context of data transfer to the Polish Scholary Bibliography
}

\begin{abstract}
Summary
The article focuses on the Ordinance of the Ministry of Science and Higher Education on the System of the Information on Higher Education and its implementation at the Wroclaw University of Science and Technology (WRUST). Some organizational solutions and communication ways with the POL-on - the System of the Information on Higher Education were presented. A special attention was paid to DONA database as the main WRUST source of reliable bibliographic and statistical data for estimation and comparison of the research performance. It discusses the way of publication data transfer to the Reporting Module of the PBN - Polish Scholarly Bibliography, especially: organization of work, modifications in DONA database structure, process of data enhancement, a new data range in accordance with the new Ministry Ordinance as well as data import details. A particular attention is given to information extension about authors, publication affiliation assignment to the university organizational unit, Open Access availability of publications, OA licenses and information about conferences. The main goal of the article is to present the experiences of the big technical university with a great practical expertise in the field of development of the complex multitask information platform - a source of information about scientific output of the University. It analyses also problems connected with the data transfer to the POL-on System and discusses the important issue such as evaluation of scientific units in Poland.
\end{abstract}

KEYWORDS: scientific output of Wroclaw University of Science and Technology, DONA database, POL-on, Polish Scholarly Bibliography. 